\title{
Irpe Neoliberal Global Remedies: From Speculative-Led Growth to IMF-Led Crisis in Turkey
}

\author{
ERINC YELDAN \\ Department of Economics, Bilkent University, Ankara, 06800, Turkey; \\ e-mail: yeldane@bilkent.edu.tr
}

Received December 23, 2003; accepted May 5, 2005

\begin{abstract}
Turkey experienced a severe economic and political crisis in November 2000, and again in February 2001. The IMF has been involved with the macro management of the Turkish economy both prior to and after the crisis, and provided financial assistance of \$20.4 billion, net, between 1999 and 2003. The official stance is that the crisis was the result of the failure of the public sector to maintain the austerity targets and the failure to fully implement the free market rationale of globalization. I argue in this article, however, that contrary to the official wisdom, the current economic and political crisis is not the end result of a set of technical errors or administrative mismanagement unique to Turkey, but is the result of a series of pressures emanating from the process of integration with the global capital markets. I document the fragility indicators of the Turkish financial and fiscal system, and show that the IMF program led to an increase in vulnerability of the financial system throughout 2000-2001. I further argue that the recent wave of structural reforms destined for stability and credibility serve, in fact, mainly the interests of foreign finance capital, and primarily aim at securing the debt obligations of the Turkish arbiters.
\end{abstract}

JEL classification: $\quad$ E6; F3; O1; O52

Keywords: economic and political crisis; Turkey; speculation-led growth; globalization; stabilization; IMF conditionality

\section{Introduction}

At the turn of the millennium, the neoliberal orthodoxy juxtaposed a new set of conditionality as part of its hegemonic agenda on the developing world: privatization, flexible labor markets, financial deregulation, central bank independence, flexible exchange rate regimes, and fiscal austerity. To this end, integration of the developing nation-economies into the evolving world financial system has already been achieved through a series of policies aimed at liberalizing their financial sectors and privatizing major industries. Furthermore, the state apparatus had to be transformed to facilitate the hegemony of international finance capital. 
The neoliberal ideology attempted to explain the motives behind financial liberalization, arguing that such measures would restore growth and stability by raising savings and improving economic efficiency. Accordingly, as the "strangulation" of the so-called financial repression was dismantled, loanable funds would expand, real cost of credit would fall, and the consequent increases in the pace of capital accumulation would generate sustained growth. This claim, referred to as the McKinnon-Shaw hypothesis, provides the theoretical backbone of the neoliberal ideology advocating financial deregulation and liberalization. ${ }^{1}$

The neoliberal dogma puts an almost religious faith in the stability characteristics of free markets. In view of that, given the undistorted price signals of free markets (as well as that of a "floating exchange rate regime"), market participants would, in an optimizing framework, smooth out their expenditure plans, and the realized production and expenditures patterns would be regarded as first-best outcomes. Thus, in a virtuous cycle of "financial deepening," international mobility of capital would help allocate savings and investments more efficiently, reducing interest costs.

The real fact of life, however, has been quite a different story than the naïve and unrealistic models of imaginary capitalism envisaged by the neoliberal orthodoxy. Following full-fledged financial liberalization, those developing economies that underwent financial deregulation found themselves trapped within high and persistent real interest rates. They also bore witness to a self-distorting foreign exchange market operating through attacks of speculative hot money flows into the fragile and shallow asset markets, luring the residents in a never-ending spiral of debt accumulation, increased dependence on imports, and jobless growth patterns.

Furthermore, contrary to expectations, the postliberalization episodes were inflicted with the divergence of domestic savings away from fixed capital investments toward speculative financial instruments with often erratic and volatile yields. As a result, developing economies with weak financial structures and shallow markets suffered from increased volatility of output growth, shortsightedness of investment decisions, and financial crises with severe economic and social consequences. Often, the economic crises were realized hand in hand with the ensuing political crises. All these led to severe contraction of labor incomes and increased unemployment together with marginalization of the workforce.

The historical importance of these crises is also revealed in their significance as a serious blunder to the neoliberal orthodoxy rather than just a simple case study in pure economic/political mishaps. The Turkish and the Argentinean crises, for example, which occurred in the midst of IMF-directed adjustment programs, became the clearest examples of how, in an indigenous economy, the unfettered workings of the myopic markets can serve as the main source of instability through the speculative attacks of international financial capital flows. Furthermore, with the recent attempts toward full liberalization of the capital account under pressures from the United States and the IMF (the so-called

1. See McKinnon (1973) and Shaw (1973). For a review on the history of the rise of the neoliberal paradigm as the hegemonic ideology in shaping macroeconomic policy, see George (2000).

2. The term Washington consensus was first coined by Williamson (1990) and then was reformulated in his 1993 article. Accordingly, a consensus on neoconservative economic policies emerged in the early 1980s that reflected trade liberalization, price reform, deregulation, and privatization of state parastatals. This consensus, he argued, "was shared by both the political Washington Congress and senior members of the administration 
Washington consensus), ${ }^{2}$ governments lost their independence in designing a strategic mix of the foreign exchange rate, the rate of interest, and fiscal policy as instruments for promotion of industrialization/development targets. As open capital markets replaced regulated flows of foreign finance, governments became unable to use their traditional policy instruments (interest rates, government expenditures, and exchange rates) unilaterally: raising interest rates higher than world markets would trigger a large foreign capital inflow, setting the stage for a financial crisis. Fixing them lower than world markets, however, would trigger a large foreign capital outflow, generating the crisis directly. Similarly, setting exchange rates higher than equilibrium levels could lead to a current account deficit; fixing them lower than equilibrium would stimulate capital flight and investment abroad, preparing grounds for a currency crisis. Finally, running a budget deficit to stimulate growth or provide social programs more generous than the international norm is prone to capital outflows. What is more, flexible exchange rates amplify the effects of these international capital flows by allowing speculation on foreign exchange markets that are excessively large, excessively liquid, excessively volatile, imperfectly informed, and subject to herd psychology.

After going through a series of short-term cycles of instability-crisis, (unsustained) growth - throughout the 1990s, Turkey entered a period of severe economic-cum-political crisis starting in November 2000. Even though the making of the Turkish crisis has been the topic of many excellent analyses thus far, ${ }^{3}$ I find it pertinent to offer a thorough evaluation of the official policies of crisis management before and during the crisis, and to evaluate the utilization of the IMF's financial support from 1998 to date. Thus, rather than a historical portrayal of events leading to the crisis of 2000-2001, it is the purpose of this article to provide an in-depth analysis of the real (hidden) objectives of the economic/ social/political policies implemented under supervision of the IMF throughout the course of the crisis.

The plan of the article is as follows: in the next section, I provide a brief overview of the post-1980 liberalization path of the Turkish economy. In section 3, I review the conditions leading to the 2000-2001 financial crisis, emphasizing the role of the IMF's program, and examine the financial and fiscal fragility indicators of the Turkish economy. Section 4 documents the composition of foreign debt and the extent of the IMF's financial assistance to Turkey. Section 5 summarizes and concludes.

and the technocratic Washington of the international financial institutions, the economic agencies of the US government, the Federal Reserve Board, and the think tanks" (Williamson 1990: 28). The concept then was revived and redressed in many situations during the 1990s, and after much prodding came to be referred to as the augmented Washington consensus to oversee the new jargon of neoliberal orthodoxy such as financial prudential regulation, central bank independence, inflation targeting, and governance. A thorough assessment of the concept is provided in Rodrik $(2002,2003)$ and Broad and Cavanagh (2000).

3. See, for example, Akyüz and Boratav (2003); Boratav and Yeldan (2002); Yeldan (2002); Celasun (2002); Alper and Öniş (2003); Cizre and Yeldan (2005); Voyvoda and Yeldan (2002); Turkish Independent Social Scientists Association-Economics Group (2001); Ertugrul and Selçuk (2001, 2002); Gençay and Selçuk (2001); Yentürk (2001); Uygur (2001); Boratav (2001); Ersel (2000); Yenal (2000); Celasun (2001); and Yeldan (2001a, 2001b, 2001c). Most of the analyses on the crisis are presented at the International Development Economics Associates (IDEAs) Web site, http://www.ideasnetwork.org; and the Turkish Independent Social Scientists Association—Economics Group Web site, http://www.bagimsizsosyalbilimciler.org/iktisatg.htm. 


\section{Financial Liberalization and Speculative-Led Growth in Turkey}

Turkey's post-1980 history of macroeconomic and political developments is observed to suffer persistent difficulties and wide fluctuations in national income, with conflicting policy adjustments. This observation parallels closely the overall thematic continuity of the ambitious program of economic liberalization and market-led adjustments put into full force during the early 1980s. At the turn of the third millennium, the most visible aspects of the current Turkish political economy context are the persistence of price inflation under conditions of a crisis-prone economic structure, persistent and rapidly expanding fiscal deficits, the marginalization of the labor force along with the dramatic deterioration of the economic conditions of the poor, and the severe erosion of moral values with increased public corruption.

In Table 1, I tabulate the broad economic indicators and key macro prices of the Turkish economy. The post-1980 Turkish adjustment path can be partitioned into two broad phases: 1981-1988 and 1989-2003. The main characteristic of the first phase is structural adjustment with export promotion, albeit under a regulated foreign exchange system and controls on capital inflows. During this period, integration into the global markets was achieved mainly through commodity trade liberalization. More important, both the exchange rate and direct export subsidies acted as main instruments for the promotion of exports and pursuit of macroeconomic stability. The period was also characterized by a severe suppression of wage incomes via hostile measures against organized labor. This "classic" mode of surplus creation $^{4}$ reached its economic and political limits by 1988. Coupled with a new wave of populist pressures under approaching elections, organized labor succeeded in attaining significant increases in wages. Real wages in manufacturing, for instance, increased by 90 percent in cumulative terms between 1989 and 1991. Furthermore, beginning in 1989, there has been a major shift in the public expenditure accounts toward more socially desirable ventures. An overall increase in both the share and level of public salaries, and investments on social infrastructure, enabled the working masses to attain improved living standards.

The post-1988 structural shift could evidently be financed by taxing the bourgeoisie and by moving toward a more "fair" tax system. Yet, the strategic preference of the state was the maintenance of its present stance toward evasion of taxable capital incomes and of its lax attitude toward the so-called unrecorded private transactions. In this sense, one can easily argue that the strategic choice of the state to abstain from expanding its tax base over capital incomes has long created a structural fragility in the fiscal accounts. Through this mechanism, the appropriated surplus could have been kept within the confines of private capital and, as such, has constituted one of the major sources of capital accumulation under conditions of peripheral capitalism.

The main macroeconomic policy response to the increased wage costs and culminating fiscal deficits was complete deregulation of financial markets. With the advent of elimination of controls on foreign capital transactions and the declaration of convertibility of the Turkish lira (TL) in 1989, Turkey opened up its domestic asset markets to global financial competition. In this setting, the Central Bank (CB) lost its control over the exchange rate and the

4. Following Lippit (1985), I use the term surplus creation to refer to that portion of the GDP that is higher than that which is necessary to meet the socially determined subsistence requirement. See Yeldan (1995) and Somel (2003) for an application of the concept to the Turkish economy. 


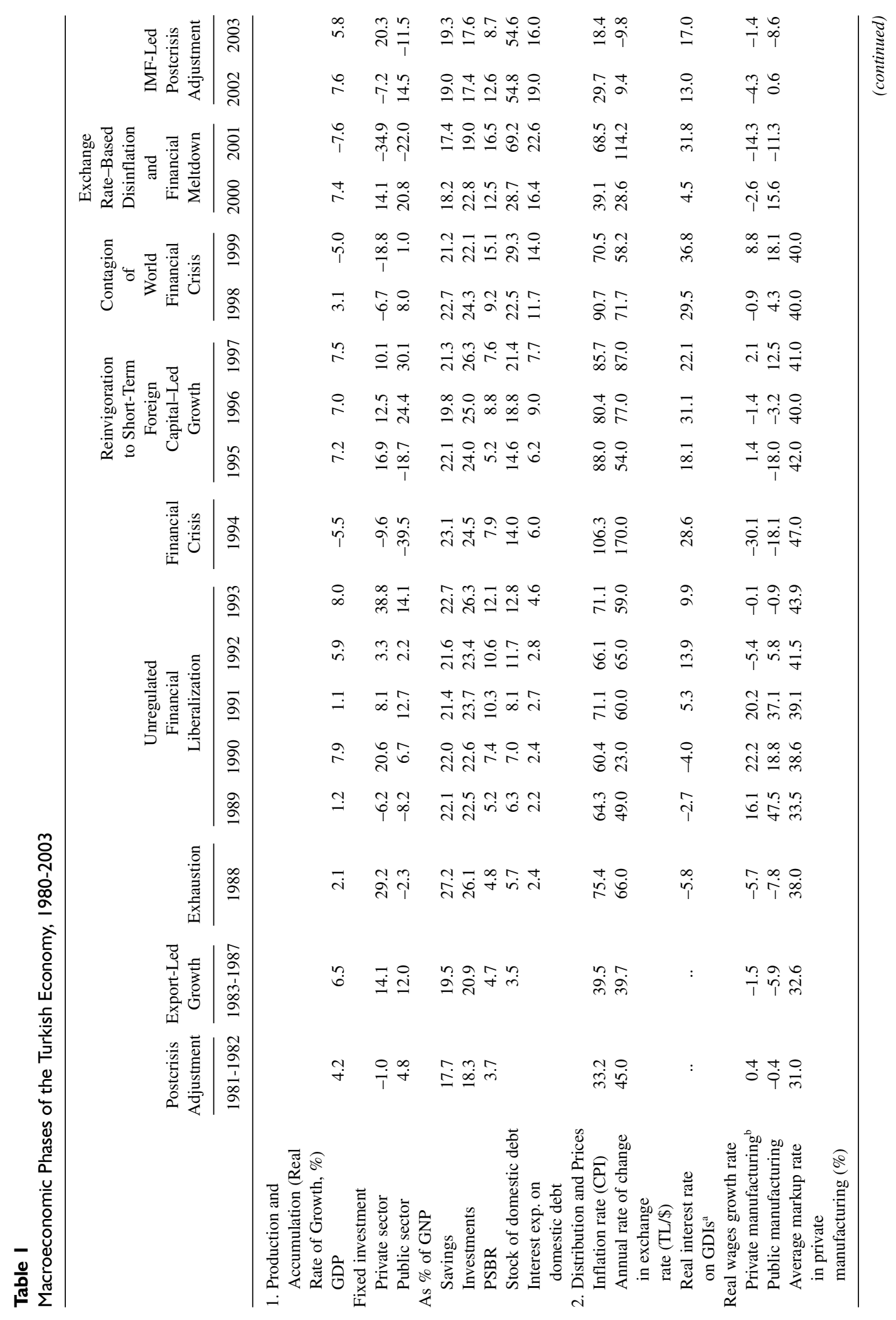




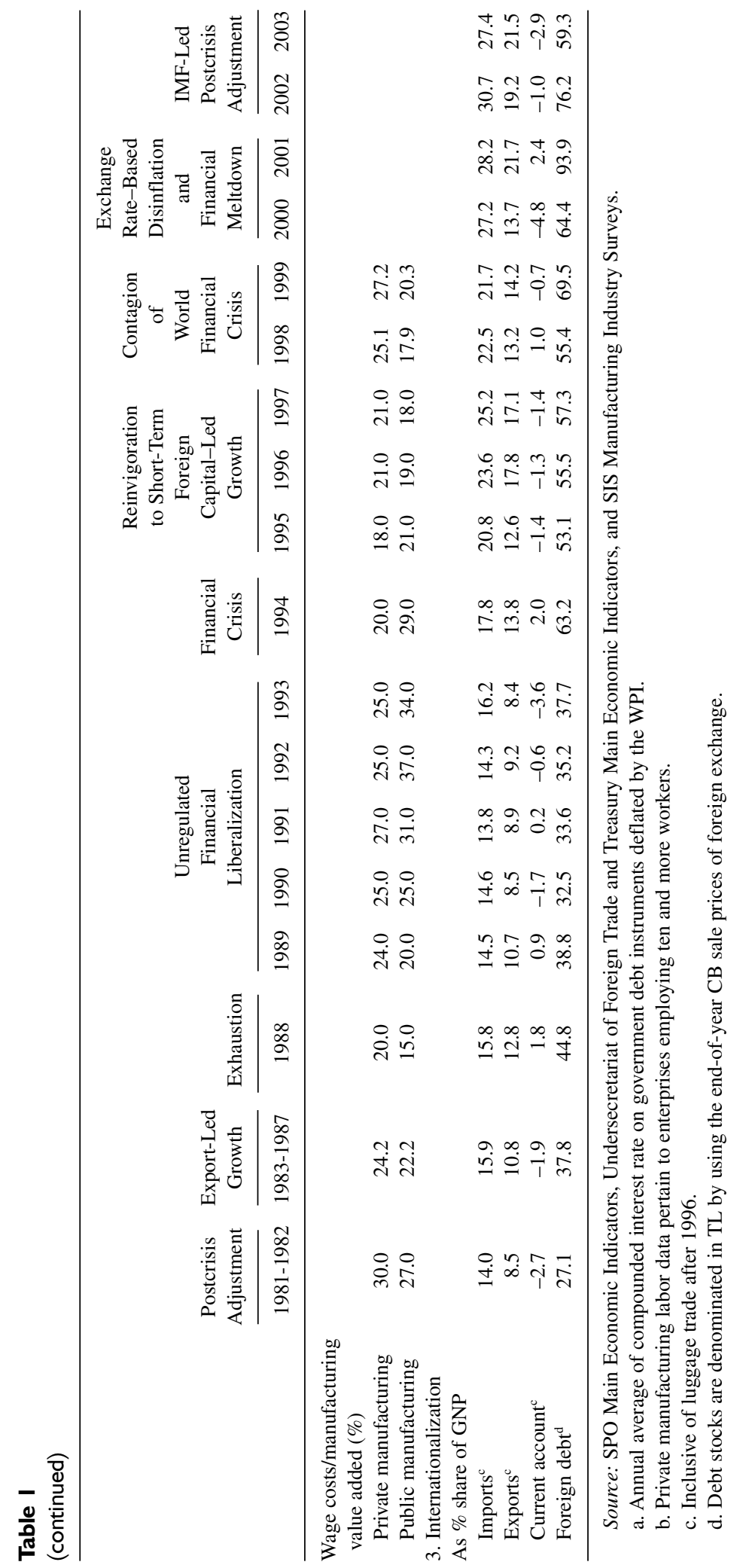


interest rate as policy instruments independent of each other because these practically turned into exogenous parameters set by the chaotic conditions of financial arbitrage in the global markets. Thus, many scholars regard 1989 as a crucial year, segmenting the post-1980 economic development patterns of Turkey (see, e.g., Boratav, Yeldan, and Köse 2000; Yentürk 1997; Ekinci 1998).

Given this broad division, the Turkish economy is observed to go through four distinct cycles of growth, crisis, and adjustment. (See characterization in Table 1.) The first covers broadly the period 1980-1988, with its main attribute being the increased export orientation of the economy. Following the foreign exchange crisis of 1977-1980, growth was reinvigorated through the introduction of a structural adjustment program in January 1980 under the auspices of the World Bank and the IMF. The period was marked with commodity trade liberalization and export promotion along with price reform aimed at reducing the state's role in economic affairs. After the brief slowdown in 1988, the 1989 policy maneuver of capital account liberalization served as one of the major policy initiatives to a new round of growth. This policy maneuver paved the way for injection of liquidity into the domestic economy in terms of short-term foreign capital (flows of "hot money"). Such inflows enabled, on one hand, financing of the accelerated public sector expenditures, and provided, on the other hand, relief from the increased pressures of aggregate demand on the domestic markets by way of cheapening costs of imports. Consequently, the bonanza of cheap imported intermediates fueled the second wave of the "growth crisis" cycle between 1990 and 1994.

Rising current account deficits (as a ratio to the GNP, from 1.7 percent in 1990 to 3.6 percent in 1993) and a drastic deterioration of fiscal balances (with the public sector borrowing requirement [PSBR] increasing its ratio to the GNP from 7.4 percent to 12.1 percent during the cycle) signaled the unsustainability of the post-1990 growth path. This prolonged instability reached its climax during the fourth quarter of 1993, when currency appreciation and the consequent current account deficits rose to unprecedented levels. With the sudden drainage of short-term funds in the beginning of January 1994, production capacity contracted, followed by continued fall in industrial output throughout that year. Together with this contraction, the post-1994 crisis management gave rise to significant shifts in income distribution and to an intensification of the ongoing processes of transfer of the economic surplus from the industrial/real sectors and wage labor, in particular, toward the financial sectors. Likewise, dollar-denominated wage costs decreased substantially and enabled export earnings to rise. In fact, the disequilibrium could have only been accommodated by the massive (downward) flexibility displayed by real remunerations of wage labor. (See Figure 3.) Manufacturing real wages declined by 30.1 percent in the private sector and 18.1 percent in the public sector in the aftermath of the 1994 crisis. Concurrently, the average markup rate in private manufacturing reached its highest value (47 percent) of the whole post-1980 liberalization era.

Growth was reinvigorated after 1995 . This third cycle was again characterized by massive inflows of short-term foreign capital (hot money) lured by attractive real rates of interest and the appreciation of the TL. The cycle proved likewise unsustainable as the global deceleration following the contagion of the Asian and Russian financial crises hit the Turkish economy starting in August 1998.

To combat the increased instability and fight against the ongoing inflation, the $\mathrm{CB}$ and the Undersecretariat of Treasury started to implement a disinflation program in December 1999 under the guidance and direct supervision of the IMF. The main elements of the program were 
the use of the exchange rate as a nominal anchor, the implementation of a semicurrency board regime by restricting the monetary expansion to increases in the net foreign assets of the $\mathrm{CB}$, and a policy of no sterilization ${ }^{5}$ to ensure rapid declines in the interest rate.

During the course of the program, the real GDP, which fell by 5 percent in 1999, expanded at a rate of 7.6 percent in 2000, the fourth growth cycle, but drifted into negative quarterly rates of growth following the first quarter of 2001. Of the expenditures over the GDP, the deepest slump was witnessed in fixed investments, with contractions of -41.5 percent and -50.2 percent in the second half of 2001. Fixed investment expenditures were observed to continue their contractionary trend during the first two quarters of 2002, with real rates of growth of -26 percent and -1 percent.

The most direct indicators of the crisis over the financial markets were the rapid rate of depreciation of the TL and the sudden hike of the rates of interest on the government's debt instruments (GDIs). After the second quarter of 2001, the TL-U.S. dollar parity increased by quarterly rates of 96.5 percent, 116.5 percent, and 114.5 percent, and stabilized only after November 2001. It was observed, however, that the rise in the real rate of interest of the GDIs reached 117.5 percent in the first quarter of 2001.

Labor markets became once again the main absorber of the shocks of the crisis. Manufacturing real wages took a toll by sharp decreases of 14.3 percent in the private sector and 11.3 percent in the public sector. At the same time, the open rate of unemployment rose abruptly to more than 8 percent (see Figure 4).

Given reopening of the credit lines and resurgence of short-term foreign capital, Turkey has reentered a new phase of growth driven by cheap imports and an overvalued TL starting in 2002. In 2003, the TL was overvalued by more than 30 percent against the U.S. dollar in purchasing power parity terms. Cost savings enabled by cheap foreign exchange fueled import demand, and by the end of 2004, the Turkish current account deficit had already widened to higher than 5 percent of GNP. It is not clear how long this new (fifth) cycle of growth will last given rising external fragility and the volatile perceptions of financial investors.

\section{I Elements of Speculative-Led Growth}

The increased dependence of the Turkish economy on speculative short-term capital (hot money) flows during the post-1989 financial liberalization era is evident from the above discussion. In fact, capital account liberalization in August 1989 increasingly forced the Turkish economy to become dependent on the newly emerging financial cycles, and the arbitrage-seeking inflows and outflows led to deepening external and domestic instability.

To highlight this dependent mode of economic growth, I portray in Figure 1 the movement of net financial flows from the balance of payments data and contrast it with the growth of real GDP. The figure underscores the observation that under the deregulated financial environment, sources of growth originated not from domestic capital accumulation but from the ad hoc and often irrational decrees of foreign (speculative) financial capital. In periods of

5. Under this policy stance, the CB has announced that it would not conduct contractionary open market operations to sterilize the inflow of foreign capital. Thus, given the programmed restrictions on domestic credit availability, the rate of growth of the domestic money supply was effectively determined by inflows of foreign capital. This had the effect of a "currency board" regime as in Argentina during the 1990s. 


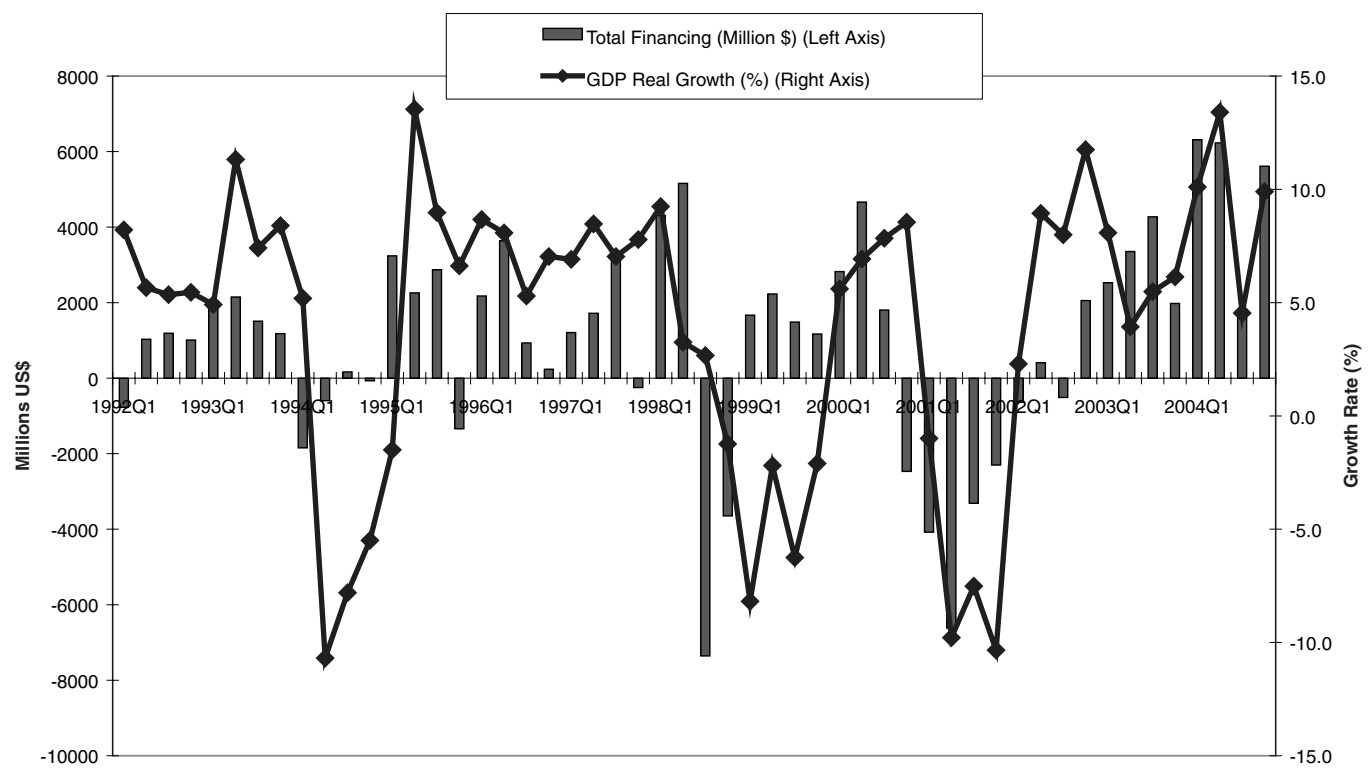

Figure 1 .

Balance of Payments Finance Account + Net Errors and Omissions (Millions \$) and Real Growth Rate of GDP (\%)

high inflows of financial capital, growth rates of the GDP tend to increase, yet periods of capital flight mean direct recession-even outright collapse, as in 1994, 1999, and 2001.

Under these conditions, whatever the growth performance of the economy during the post-capital account liberalization, it had to be based on speculative-led patterns, a term coined initially by Grabel (1995). Consequently, finance was elevated over industry and the real sphere of the economy, and the financial sector drifted to the speculation of short-term capital flows in a process that has been characterized as casino capitalism (Strange 1986).

Thus, after 1989 the growth performance of the Turkish economy is observed to follow directly the direction of flows of foreign financial capital. In 2003 as well, the fact behind the positive rate of growth is understood to be inflows of foreign capital. As a "new emerging market," Turkey is able to attract such capital inflows with the aid of high rates of financial arbitrage that it offers in the international capital markets. This financial arbitrage can be calculated as the end result of an operation that first converts foreign exchange into TLs at the initial rate of exchange and, after earning the rate of interest $R$ offered in the domestic asset markets, reconverts it back to the foreign currency at the then prevailing foreign exchange rate. Algebraically, this net arbitrage gain is calculated as

$$
\frac{1+R}{1+\varepsilon}-1
$$

Thus, during the course of this operation, financial speculators would gain the domestic rate of $R$ and lose at the rate of depreciation of the TL, $\varepsilon$. The net difference between 


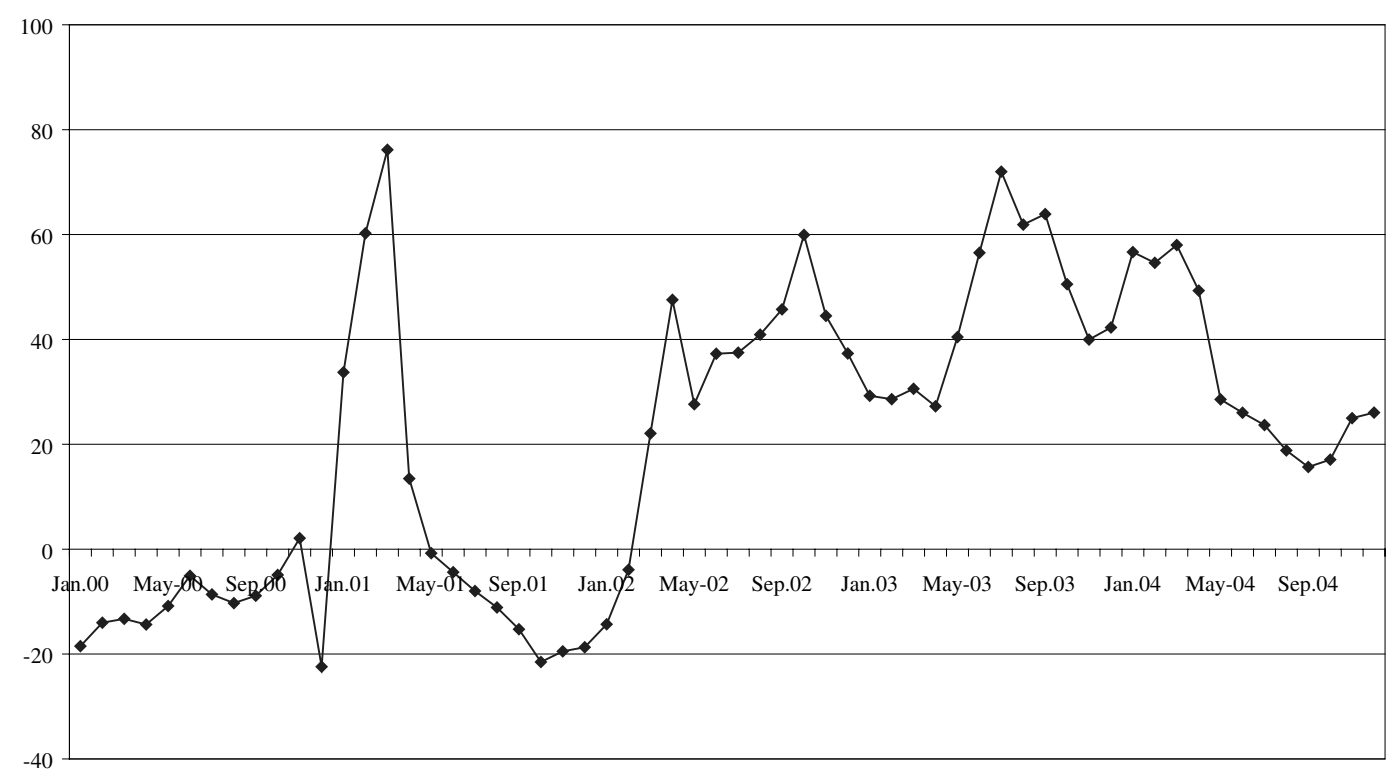

Figure 2.

Speculative Financial Arbitrage (\%)

the two prices would give us the net financial arbitrage gain. I calculate the evolution of such gains in Figure 2. Here, the main hypothesis is that the financial arbitrageurs would invest their foreign monies in the domestic instrument that would bring the highest rate of return in the domestic asset markets (in most cases, the GDIs).

According to the calculations portrayed in Figure 2, Turkey offered real rates of 80 percent during the February crisis of 2001, 60 percent in December 2002, and 75 percent in the summer of 2003, and thus became one of the leading emerging markets in the world of financial speculation. Whereas the U.S. and OECD interest rates were at 2.5-4.0 percentage levels, Turkey continued to offer arbitrage gains over dollar-denominated assets reaching 30 percent. Such returns enabled Turkey to attract huge sums of speculative finance capital with a significant "hot" component especially during 2003 and 2004.

It would definitely be unrealistic to sustain fixed investments within an economy offering such rates of return to speculative financial transactions. As a matter of fact, in the aftermath of the 2001 crisis, fixed investments virtually stagnated and did not exceed their real 1998 levels as of 2004. I tabulate data on fixed investments in Table 2.

Such a transfer of financial surplus through very high real interest rates offered to the financial system would, no doubt, call for repercussions to the primary categories of income distribution. It is clear that creation of such a financial surplus would directly necessitate a squeeze of the wage fund and a transfer of surplus away from wage labor toward capital incomes, in general. It is possible to find evidence of the extent of this surplus transfer from the path of private manufacturing real wages. I portray the dynamics of the private manufacturing real wages in Figure 3, denominated in both TL and U.S. dollar terms. The figure further contrasts real wages against labor productivity. 


\section{Table 2}

Private Fixed Investment by Sectors, 1998-2004

\begin{tabular}{|c|c|c|c|c|c|c|}
\hline & 1998 & 2000 & 2001 & 2002 & 2003 & $2004^{\mathrm{a}}$ \\
\hline \multicolumn{7}{|l|}{ 1. Distribution by Sectors (\%) } \\
\hline Real production sectors & 28.3 & 30.4 & 28.3 & 33.4 & 44.4 & 47.6 \\
\hline Manufacturing & 22.4 & 26.7 & 24.6 & 29.7 & 39.5 & 42.3 \\
\hline Agriculture and mining & 5.9 & 3.7 & 3.7 & 3.7 & 4.9 & 5.3 \\
\hline Services & 71.7 & 69.6 & 71.7 & 66.6 & 55.6 & 52.4 \\
\hline Transportation & 19.7 & 26.2 & 23.4 & 26.0 & 17.0 & 21.0 \\
\hline Housing & 36.8 & 23.7 & 23.9 & 17.0 & 14.4 & 11.8 \\
\hline Tourism & 3.6 & 5.6 & 6.2 & 6.8 & 8.6 & 7.2 \\
\hline Others $^{\mathrm{b}}$ & 11.5 & 14.1 & 18.2 & 16.6 & 15.6 & 12.4 \\
\hline \multicolumn{7}{|c|}{$\begin{array}{l}\text { 2. Index of Fixed Investment } \\
\text { by the Private Sector }(1998=100)\end{array}$} \\
\hline Private & 100 & 89 & 64 & 55 & 66 & 93 \\
\hline Manufacturing & 100 & 107 & 68 & 73 & 116 & 176 \\
\hline Transportation & 100 & 119 & 73 & 72 & 57 & 100 \\
\hline Housing & 100 & 58 & 40 & 25 & 26 & 30 \\
\hline Public & 100 & 128 & 90 & 100 & 94 & 97 \\
\hline Total & 100 & 99 & 69 & 66 & 73 & 94 \\
\hline
\end{tabular}

Note: Total may not add up to 100 due to rounding.

a. Program forecast.

b. Energy, education, health, and other services.

After a brief surge throughout 1990-1993, real wages had plummeted during the 1994 financial crisis and in a sense have borne the brunt of the adjustment of the crisis. During 1995-2000, private manufacturing real wages have kept their momentum in general, although they could not recover their pre-1994 crisis levels. After the 2000-2001 waves of crises, however, real wages in private manufacturing faced a second cycle of contraction. This contraction was especially pronounced in U.S. dollar terms. In the meantime, productivity gains in private manufacturing accelerated, especially after the first quarter of 2002. It is known that this productivity surge was due mostly to labor shedding (see Figure 4 on rates of unemployment) rather than increased labor efficiency originating from advances in technology. As of the last quarter of 2003, the index of labor productivity scored 1.77-fold higher than real wages in TL and 2.29-fold higher than the unit wage costs in U.S. dollars.

A close inspection of figures 2 and 3 together is especially informative. This exercise shows clearly how in the Turkish economy speculative financial gains were financed through squeezing real wages. Each rapid rise in the financial arbitrage is closely associated with a downward movement of real wages and involves a direct transfer of labor incomes toward capital, both domestic and foreign. The real wages contracted severely after the February 2001 crisis, and this downward trend was maintained throughout 2002 and 2003. Calculated from 2000 to mid-2003, the decline in the private manufacturing real wages reached 19.6 percent. The decline of wages in the public manufacturing sector has been 15.4 percent during the same period. Viewed from a longer time horizon, if the index 


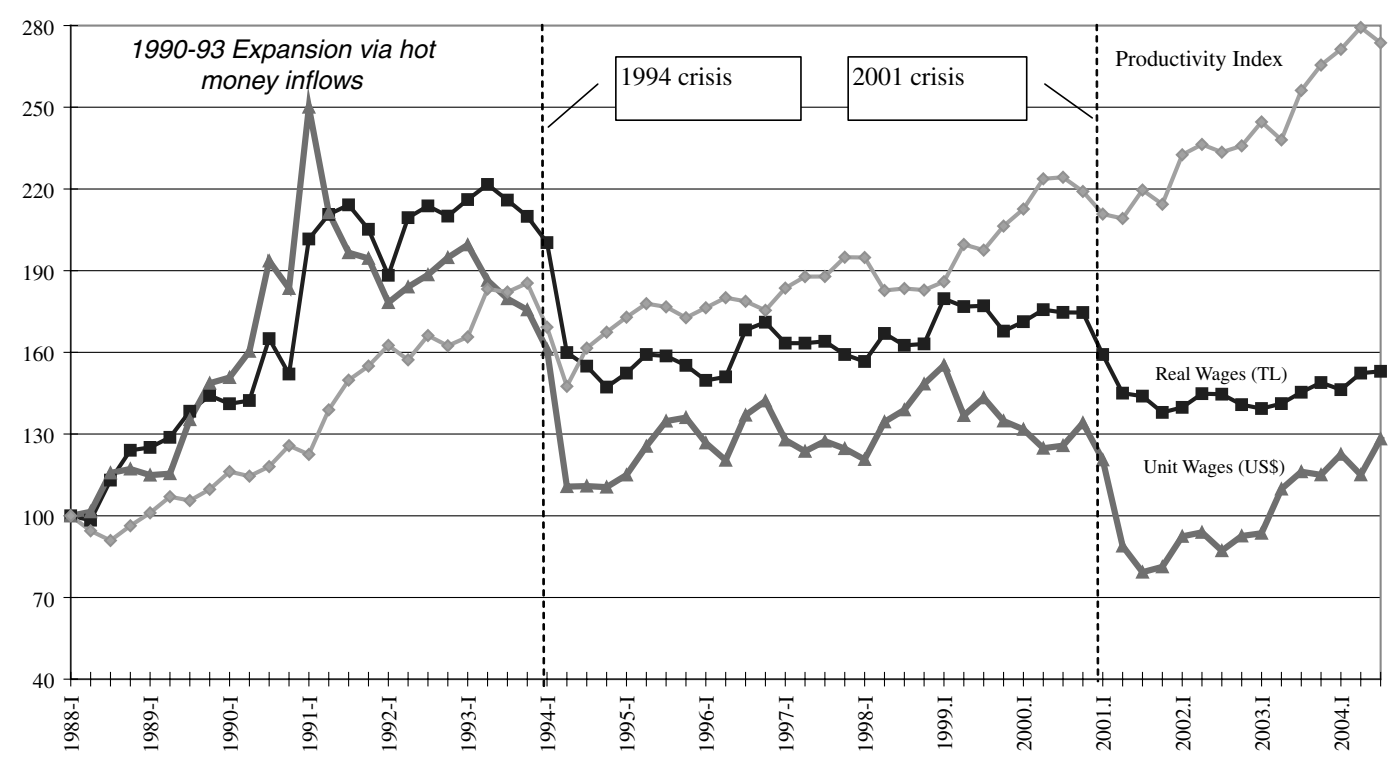

Figure 3.

Productivity and Real Wages in Turkish Private Manufacturing

of real wages were assumed to be 100 in 1997, it is observed that they fell to 82.2 index points in the private manufacturing sector.

Parallel to these developments in the labor markets, there was a surge in unemployment rates. The open unemployment rate was 5.6 percent in 2000. In 2001, the official rate of open unemployment rose to 8 percent and accelerated to 10.3 percent in 2003, staying at that level since then. (See Figure 4.) More alarmingly, the rate of unemployment among the educated urban young labor force was reported to reach 31.1 percent by the end of 2003. This ratio was 28.7 percent in 2001. Thus, the problem of unemployment persists and is actually deepening in the absence of new investments and an ideological preference toward contraction and austerity in the name of stabilization and debt repayments.

\section{Financial and Fiscal Fragility of the Turkish Economy}

At this point, I find it necessary to highlight the main causes and the structural sources of the crisis in the Turkish context as an emerging market. The crisis, which first revealed itself as a warning signal in November 2000 and erupted in full scale in February 2001, is explained in the official circles and in the popular media as a result of "the failure of the Turkish bureaucracy to implement the necessary structural adjustment reforms on time, thereby disturbing the market agents and letting foreign capital to leave the country."

This view, which portrays Turkey as a misbehaved student in the global markets, has also been reflected in the official documents of the post-February 2001 crisis era and as such has become the main ideological theme of the measures of new conditionality. As a vivid 


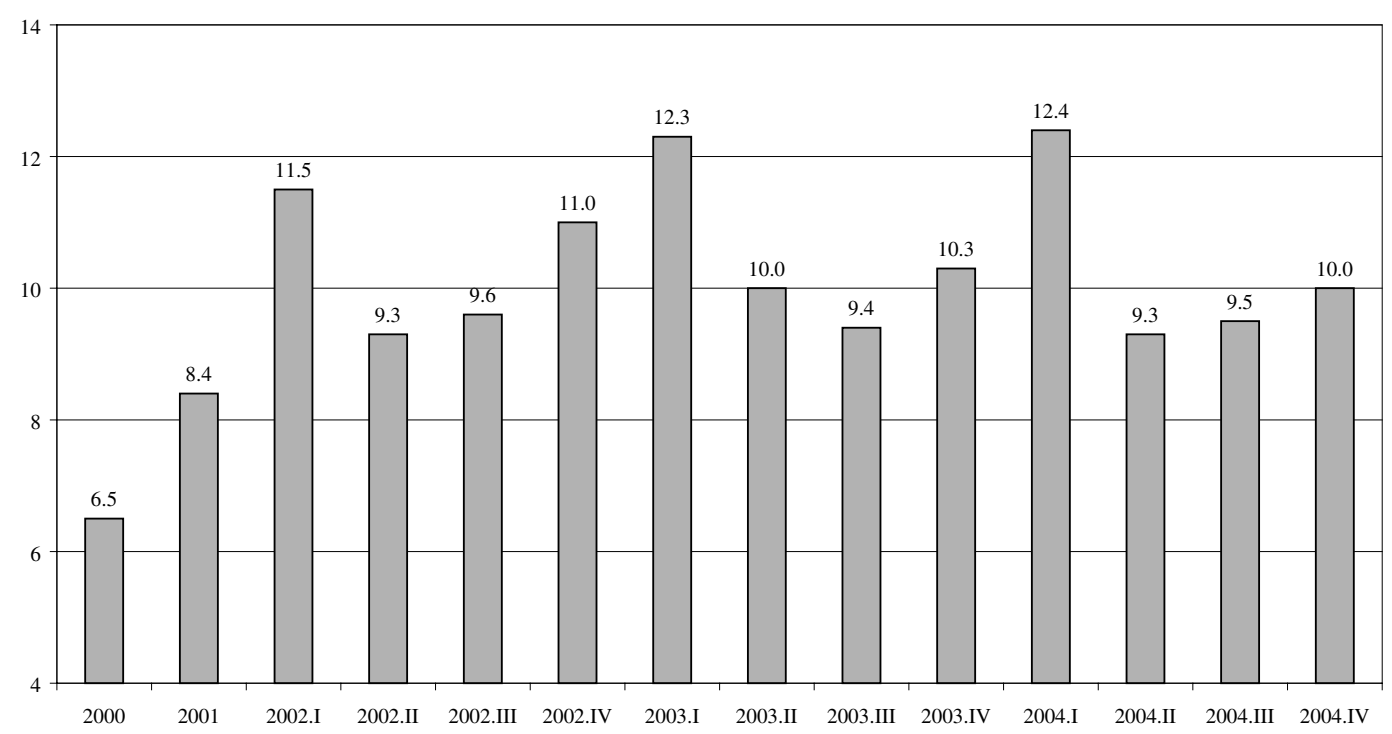

Figure 4.

Open Unemployment Rate (\%)

example of this official rhetoric, one can cite the words of Kemal Dervis, who resigned from his post as a vice chair of the World Bank in the immediate aftermath of the February crisis and has assumed a leading role as the new state minister: "with the implementation of a more stringent fiscal policy, the crisis might perhaps have been alleviated. Unfortunately, the fiscal policy had not been strong enough, and the current account deficit widened." 6

According to this remark, the main source of the Turkish crisis was the rapid widening of the current account deficit. This interpretation, without doubt, is true given the numerical indicators of the crisis. The current account deficit, which was $\$ 1.3$ billion in 1999 , erupted to reach $\$ 9.8$ billion in 2000 . The deficit in the current account, which reached 4.8 percent as a ratio to the GNP, is one of the clearest indicators of the crisis. Yet, the main issue here is to discuss the main reasons behind this deterioration, rather than highlighting the deterioration itself, which is merely an end result. In fact, the proposition set forth by Dervis accusing the lax fiscal administration as the main source of the current account deficit does not fit with the facts. Data from the consolidated central budget and other fiscal accounts clearly underscore that the public sector had not suffered from a deficit exceeding the planned or foreseen magnitude and that during 2000 and 2001, the Turkish government had in fact followed a strongly contractionary policy in terms of meeting its overall expenditures.

Data on 2000 and 2001 consolidated budget revenue and expenditure realizations disclose that fiscal accounts were in line with targeted values. Fiscal data reveal that realizations of budgetary revenues exceeded their targets by 3.6 percent in 2000 and by 5.1 percent in 2001. Expenditures, however, are observed to be lower than their targeted limit 
by 0.2 percent in 2000 and exceeded their target only marginally by 1.7 percent in 2001 . Thus, during both years, the public sector succeeded in attaining its fiscal targets and increased its noninterest (primary) budget surplus to 6.1 percent of GNP in 2000 and to 6.7 percent of GNP in 2001. This "success" in the fiscal balances was the direct end result of the severe contraction in public investments and other social expenditures, as well as the enactment of extraordinary earthquake taxes during $2000 .^{7}$

Thus, the official/popular explanation of the crisis in terms of "excessive fiscal deficits" is totally flawed and serves only as propaganda for masking the dynamics behind the evolution of the crisis. Yet, a close inspection of the precrisis macroeconomic balances of the Turkish economy clearly underscores that the continued volatility and disruption in the economy should not be regarded as the results of a few technical errors in fiscal administration or bureaucratic mismanagement, but should be viewed as direct outcomes of the neoliberal policies of the post-1980s that have sought to leave the domestic economy defenseless against unfettered market forces, which are excessively myopic, excessively erratic, and subject to herd behavior.

The 2000 disinflation program had, in fact, dispossessed the CB of its traditional tools of austerity by limiting monetary expansion only to increases in the stock of net foreign assets. According to this rule, the liquidity generation mechanism available to the CB practically meant a regime of a semicurrency board in monetary operations. Within this mechanism, monetary policy was restricted to the direction of foreign exchange flows, and, as such, the most important element to be able to sustain the liquidity needs of the economy relied on the continuation of inflows of international speculative financial capital. Thus, operating under conditions of a freely open and unregulated capital account (since 1989), the domestic rate of interest became totally dependant on availability of foreign capital, and the domestic asset markets were left defenseless against speculative runs of financial arbiters.

To be able to take better account of the disruptive mechanisms of this structural fragility, one has to note the famous trilemma underlying an open economy that the international economists are fond of. In an open economy, the monetary authority can independently choose only one of the three following instruments: the nominal exchange rate, the interest rate, and the stock of money, leaving the determination of the other two to the interplay of market forces. As discussed above, liberalization of the capital account intrinsically necessitates a higher rate of return on domestic assets in comparison to the rate of depreciation of domestic currency against foreign currencies. This commitment stimulates further foreign inflows, and domestic currency appreciates, inviting an even higher level of hot money inflows into the often shallow domestic financial markets. The initial bonanza of debt-financed public (e.g., Turkey) or private (e.g., Mexico and Korea) spending rapidly escalates the acute fragility of shallow financial markets in the home country. Eventually, the bubble bursts, and a series of severe and onerous macro adjustments are enacted through very high real interest rates, sizable devaluations, and a sharp entrenchment of aggregate demand, while the short-term hot money flows have already rushed out of the country, leaving it broke and deprived of the traditional tools of adjustment and austerity. Elements of this vicious cycle are further studied in Polanyi-Levitt (2001); Adelman and Yeldan (2000);

7. See Ertugrul and Yeldan (2003) and Yeldan (2002) for further evidence and discussion on the fiscal performance of the Turkish economy under the IMF's 2000 program. 
Calvo and Vegh (1999); Rodrik and Velasco (1999); Dornbusch, Goldfajn, and Valdés (1995); Velasco (1987); and Diaz-Alejandro (1985), and are more recently referred to as the Neftçi-Frenkel cycle in Taylor (1998, following Neftçi 1998 and Frenkel 1998).

In the context of the Turkish liberalization episode, the lure of uncontrolled flows of speculative gains clearly unleashed all its might throughout 2000, during which currency risk was eliminated and the whole liquidity generation mechanism was based on shortterm, hot money inflows. Yet, with the observed deterioration of macroeconomic conditions, foreigners started to pull their financial capital out of Turkey. In the last week of November 2000 alone, Turkish financial markets lost $\$ 5.3$ billion via nonresidents' shortterm speculative operations. In fact, with this rapid change of direction, net flows of nonresidents' foreign capital would turn to $-\$ 8.7$ billion after November. To these numbers one should also add the monies taken out by the resident financiers. Data reveal that during 2000-2001, residents transferred a net sum of $\$ 7.1$ billion abroad. ${ }^{8}$ This means that following November 2000, Turkish asset markets' loss of foreign exchange reached \$31 billion $(\$ 15.2+\$ 8.7+\$ 7.1$ billion) during the course of the crisis.

It is evident that, faced with these numbers, not only a financially shallow emerging market economy such as Turkey, but no economy, could endure the disruptive consequences of such financial shocks. Yet, the 2000 disinflation program completely ignored the fragile conditions of the Turkish financial and asset markets, and exclusively disabled both the monetary (the CB) and the fiscal (the Treasury) authorities from using their traditional tools of austerity by way of rendering them powerless against the speculative forces of the markets. The crisis was, in fact, the end result of the culminating pressures of this fragile environment.

As a concluding overview of this section, I can summarize the dynamics of the post1989 macroeconomic equilibrium of the Turkish economy with the aid of Figure 5. Low savings along with stagnant investments, high fiscal costs and tax evasion, and an oligopolistic structure set the stage portrayed in Figure 5. ${ }^{9}$ It can be argued that these structural traits were part of the Turkish economy throughout its history as a peripheral economy. The resolution of these imbalances, however, disclosed quite different modes of adjustment following the 1989 opening of the economy to global financial competition. Important additions to the characteristics of the period were the wage explosion and the reemergence of a populist stance against the background of intensified political struggle. In response to these structural features, I observed the state assuming an active role in the economic sphere, regulating the distribution of national output. The state carried out this task first through its enterprise system by a mandated policy of delayed price adjustments on the intermediates and the final wage and capital goods produced by the state economic enterprises (SEEs; see Figure 5, box 3). Second, following the full deregulation of the capital account, the state actively participated in the domestic asset markets through its issues of debt instruments (channels 6 and 7). This, together with the threat of currency substitution in the context of a convertible currency regime, necessitated high interest rates (channels $8 \mathrm{a}$ and $8 \mathrm{~b}$ ), the first vicious circle, and real appreciation (channel 9b).

The second vicious circle surrounding channels $9 \mathrm{a}, 9 \mathrm{~b}$, and $9 \mathrm{c}$ is highlighted by double-sided implications among the three variables involved: short-term capital inflows

8. Calculated from the balance of payments statistics, TR CB.

9. Figure 5 and the ongoing discussion are adapted from Boratav, Yeldan, and Köse (2002). 


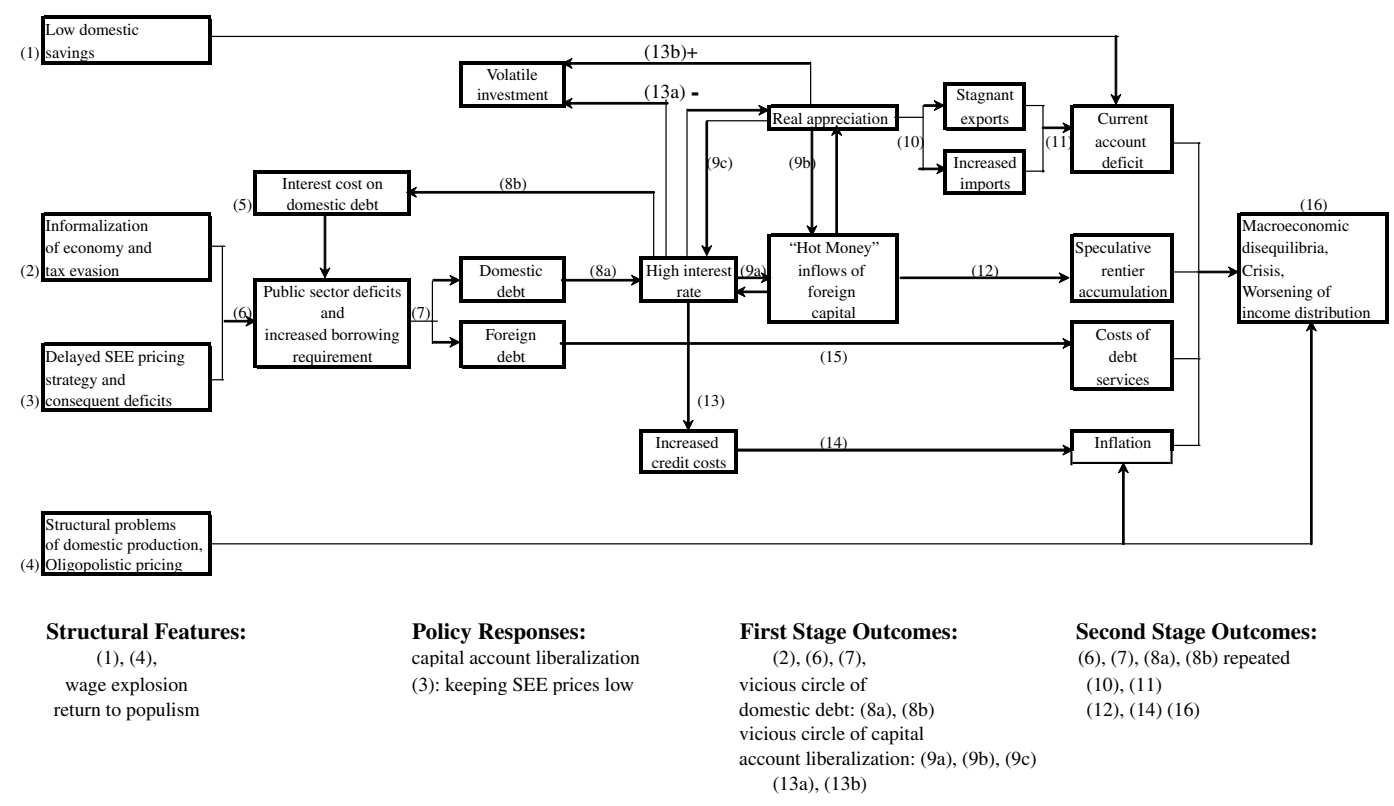

Figure 5.

Macroeconomic Dynamics of the Turkish Economy under Full Financial Liberalization (1989- ) Note: Figure adapted from Boratav, Yeldan, and Kose (2002).

(hot money), real appreciation, and high real interest rates. Real appreciation had been the prime cause of the rise of import volume and current account deficits. Real appreciation, however, had a direct positive effect on investment demand by reducing costs of imported capital goods and intermediates (channel 13b). This positive effect was countervailed by the pressures of real interest rates (channel 13a), the end result being increased volatility of investment demand. High interest rates gave way to inflationary pressures through increased costs of credit (channels $8 \mathrm{~b}$ and 13) and fed a speculative rentier type of accumulation (channel 12) with consequent worsening of income distribution.

The limits of this bonanza of a "short-term, foreign capital-led growth pattern" were the eruptions of the financial crises in 1994 and then again in 2001 as the ongoing fragility and the onerous adjustments the domestic economy had to face continued in culminating cycles.

\section{Portrait of the IMF's Financial Assistance and Its Disposition}

Turkey has used a total net sum of $\$ 20.4$ billion from IMF funds since the beginning of 2000. Through the course of using these funds, Turkey was conditioned to introduce a set of measures that go beyond the standard policies of austerity and was directed to reorient not only its economic but also its political apparatus. As a matter of fact, the new set of policies, which was introduced formally on April 14, 2001, under titles such as national program and then transition to the strong economy program (TSEP; Undersecretariat of Treasury 2001), asserted that 


\section{Table 3}

Breakdown of the IMF's Financial Assistance to Turkey, 1999-2004

July-December 1999

2000-2002

November-December 2000

February-March 2001

2002-2004

September 11

Total approval
Staff monitored follow-up

Standby

Extra reserve facility following the November 2000 crisis

Extra financing in response to the February 2001 crisis

Standby

Extra financing due to the international crisis

US\$31.847 billion

Realized Dispositions (Annually)

\begin{tabular}{ll}
\hline 1999 & US $\$ 288$ million \\
2000 & US $\$ 3.439$ billion \\
2001 & US $\$ 11.317$ billion \\
2002 & US $\$ 12.503$ billion \\
2003 & US $\$ 1.681$ billion \\
Total disposition & US $\$ 29.228$ billion
\end{tabular}

Payments of Capital

1999

2000

2001

2002

2003

Total payments

Net usage: total usage - payments

US $\$ 29.228$ billion - US $\$ 8.827$ billion $=$ US $\$ 20.401$ billion
US\$287 million

US\$88 million

US\$1.087 billion

US\$6.139 billion

US\$1.227 billion

US\$8.827 billion

Source: Undersecretariat of Treasury (2001). I am further indebted to Nazif Ekzen for his invaluable help for construction of this table.

the main aim of the program (was) to eliminate the instability due to lack of trust and to ... construct the necessary legal infrastructure so as to re-organize the public administration and the economic decision making processes. Accordingly, it would ... no longer be possible to go back to the old ways of decision making. ${ }^{10}$

The current IMF program in Turkey relies mainly on three pillars: (1) fiscal austerity that targets achieving a 6.5 percent surplus for the public sector as a ratio to GDP, (2) contractionary monetary policy (through an independent central bank) that exclusively aims at price stability (via eventual inflation targeting), and (3) structural reforms consisting of many of the traditional IMF demands (privatization, large-scale layoffs in public enterprises, and removal of any form of subsidies).

Both the TSEP (Undersecretariat of Treasury 2001) and Letter(s) of Intent that followed were administered under close supervision and financial assistance of the IMF. I tabulate the detailed breakdown of these disbursements in Table 3.

Given the above data, it is understood that netting out the payments of capital until 2003, Turkey received a total net sum of $\$ 20.4$ billion from the IMF during the crisis. According to the program conditions, $\$ 13.3$ billion of this sum were used by the Treasury in budgetary

10. Undersecretariat of Treasury (2001). 
finance of its domestic debt management, $\$ 7.5$ billion were used by the $\mathrm{CB}$ in strengthening its reserve position, and $\$ 1.1$ billion were used by the Treasury in its own reserves. It was also made clear by CB Governor Süreyya Serdengeçti that the resources obtained from the IMF were to be used first and foremost in "successful management of the failed banks taken under the control of the saving deposit fund, and to sustain the roll-over of the domestic and foreign debt repayments" (Undersecretariat of Treasury 2001).

Again in this conjuncture, the government has decided to issue treasury debt instruments (GDIs) totaling $\$ 8$ billion plus TL4.3 quadrillion (approximately $\$ 4$ billion) to the failed banks taken under the control of the Saving Deposit Fund, and a total of TL25.8 quadrillion (approximately $\$ 25$ billion) to the public banks that had experienced deteriorated asset positions due to "duty losses." Thus, throughout the months following the eruption of the February crisis, the government was observed to transfer an aggregate sum of approximately $\$ 40$ billion of fiscal resources to the banking sector. This sum reaches one fourth of the aggregate Turkish GNP.

Thus, it is clear that the funds obtained from the IMF are to be used primarily by the banking sector with the exclusive aim of "debt rollover." In fact, a close inspection of the patterns of foreign debt accumulation reveals the main attributes of this judgment firmly. Table 4 narrates this issue.

Total foreign debt of Turkey increased to $\$ 147.2$ billion by the end of 2003 , up from its level of $\$ 102.9$ billion in 1999. Despite this rise in the aggregate debt stock, it is observed that Turkey's short-term liabilities of foreign debt have (been) reduced during the course of the same period: the stock of short-term foreign debt that stood at $\$ 22.9$ billion at the end of 1999 and increased to as much as $\$ 28.3$ billion at the end of 2000 was reduced to $\$ 15.2$ billion in 2002 . It is understood that the underlying factor in this operation has been the domestic banking sector's performance in debt repayments. During this process, total short-term debt stock of the banking sector had increased to $\$ 16.9$ billion in 2000 from its level of $\$ 13.2$ billion. Yet, following the crisis, they "succeeded" in bringing their short-term debt down to $\$ 7$ billion by mid-2002.

Thus, throughout the postcrisis adjustments, while the Turkish financial system increased its total debt obligations with accumulated borrowings from the IMF, it was simultaneously conditioned to repay its short-term debts to foreign creditors. And all of this was trumpeted under the motto of "gaining credibility and trust in the foreign financial markets." In other words, the IMF-backed austerity program had primarily aimed at securing repayments of Turkey's short-term foreign debt and succeeded in achieving this outcome to a great extent.

\section{Conclusion: Stability and Credibility for Whom?}

It is clear that the 2000-2001 crisis administration in Turkey primarily worked as a debt management program. In this sense, it is understood that the main purpose of the IMF-led salvation packages that are hailed as big successes in the international media is actually an operation of foreign debt rollover aiming at gaining the confidence of the international arbiters and financial speculators.

The tacit dilemma faced by the Turkish authorities is simple yet bitter: for output growth to be continued, the economy became addicted to short-term foreign finance that in turn necessitated relatively high real interest rates to be offered as a "new emerging market" 
in the global financial markets. Yet, high real rates of interest run counter to the objective of debt sustainability via successful primary surplus operandi. Availability of cheap foreign exchange lured by attractive real returns thus far has become instrumental in reducing costs of imported intermediates and lowering inflationary expectations. It has also been the sole source of output growth in an otherwise contractionary macroeconomic environment.

The fact that such sources of growth virtually depend on the speculative caprices of the financial arbiters, and the increased fragility of the Turkish macroeconomic environment, however, signal an unsustainable output performance for the days to come. Such "speculativeled" characteristics of the Turkish growth cycle resemble the 1990-1993 and the 2000-2001 cycles of (unsustainable) growth/crisis/postcrisis adjustment, with bitter lessons that hopefully should have been well understood by now. Yet, the pleasures of a cheap foreign exchange bonanza together with high real rates of interest are too dear for the myopic speculators, domestic and foreign alike, and the dangers of such speculation-led accumulation seem, unfortunately, not to be appreciated yet by the so-called market participants.

I observe that what lies behind the colorful jargon of "effective and transparent government," "good governance," and "credibility" is a set of structural transformations to ultimately satisfy the needs and demands of the financial capital centers rather than the strategic requirements of the domestic economy. In essence, this model depends on the contractionary monetary and finance policies, and assumes an open (i.e., dependent on foreign capital) economic structure ensuring the liberalization of international capital flows. In this model, what is really meant by the concept of stabilization is establishing an exchange rate system purified from devaluation risk and maintaining a high real return in the national financial markets to attract inflows of foreign capital.

Neoliberal thought dictates that to take advantage of the benefits of "globalization," national central banks with autonomous monetary, interest, and exchange rate policies should not be a hindrance to international capital flows. The real objectives of this philosophy are to make the central banks be in charge of maintenance of price stability and to sustain high real returns in national financial markets. In so doing, rents allocated to finance would be secured. Public economics, however, is limited to take all measures directly to enlarge the interest area of international capital.

Departing from all these observations, it is clearly seen that the IMF-led adjustment program implemented in Turkey, with media propaganda that portrays it as "having no alternatives," is actually part of a larger project defining Turkey's role in the new international division of labor as a "new emerging market economy," wherein industrialization and development targets are abandoned, domestic commodity and asset markets are integrated with the global markets under marginalized conditions, and the domestic economy has been left unprotected and open to external shocks.

\section{References}

Adelman, I., and E. Yeldan. 2000. The minimal conditions for a financial crisis: A multi-regional inter-temporal CGE model of the Asian crisis. World Development 28 (6): 1087-100.

Akyüz, Y., and K. Boratav. 2003. The making of the Turkish crisis. World Development 31 (9): 1549-66.

Alper, E., and Z. Öniş. 2003. Emerging market crises and the IMF: Rethinking the role of the IMF in the light of Turkey's 2000-2001 financial crises. Canadian Journal of Development Studies 24 (2): 255-72. 
Boratav, K. 2001. 2000-2001 Krizinde sermaye hareketleri. Iktisat, Isletme and Finans (186): 7-18.

Boratav, K., and E. Yeldan. 2002. Turkey, 1980-2000: Financial liberalization, macroeconomic (in)-stability, and patterns of distribution. CEPA and the New School for Social Research. http://www.bilkent.edu .tr/ yeldane.

Boratav, K., E. Yeldan, and A. Köse. 2002. Globalization, distribution and social policy: Turkey: 1980-1998. In External liberalization and social policy, ed. L. Taylor. London: Oxford University Press.

Broad, R., and J. Cavanagh. 2000. The death of the Washington consensus? In Global finance: New thinking on regulating speculative capital markets, ed. W. Bello, N. Bullard, and K. Malhotra, 83-96. London: Zed.

Calvo, G., and C. A. Vegh. 1999. Inflation stabilization and BOP crises in developing countries. In Handbook of macroeconomics, ed. J. Taylor and M. Woodford, 1531-614. Amsterdam: Elsevier.

Celasun, M. 2001. Gelişen ekonomilerin dış kaynak kullanımı and finansal krizler. Doğu Batı 4 (17): 161-80.

—. 2002. 2001 krizi, oncesi ve sonrası: Makroekonomik and mali bir değerlendirme. In Küreselleşme, emek süreçleri and yapısal uyum, ed. A. Dikmen. Türk Sosyal Bilimler Derneği, Ankara, Turkey: İmge Yay.

Cizre, Ü., and E. Yeldan. 2005. The Turkish encounter with neo-liberalism: Economics and politics in the 2000/2001 crises. Review of International Political Economy 12 (3): 387-408.

Diaz-Alejandro, C. F. 1985. Good-bye financial repression, hello financial crash. Journal of Development Economics 19: 1-24.

Dornbusch, R., I. Godfajn, and R. Valdés. 1995. Currency crises and collapses. Brookings Papers on Economic Activity 2 (June): 219-70.

Ekinci, N. 1998. Türkiye ekonomisinde büyüme ve kriz dinamikleri. Toplum ve Bilim (77) (Summer): 7-27.

Ersel, H. 2000. Ekonomik istikrar and yapısal uyum programımının neresindeyiz? Iktisat, Işletme and Finans 173 (August): 7-28.

Ertugrul, A., and F. Selçuk. 2001. A brief history of the Turkish economy, 1990-2000. Russian and East European Finance and Trade 37: 6-28.

- 2002. Turkish economy: 1980-2001. In Inflation and disinflation in Turkey, ed. A. Kibritcioglu, L. Rittenberg, and F. Selçuk. Aldershot, UK: Ashgate.

Ertugrul, A., and E. Yeldan. 2003. On the structural weaknesses of the post-1999 Turkish dis-inflation program. Turkish Studies Quarterly 4 (2) (Summer): 53-66.

Frenkel, R. 1998. Capital market liberalization and economic performance in Latin America. CEPA Working Papers 1998-06, May. New York: Center for Economic Policy Analysis, New School for Social Research.

Gençay, R., and F. Selçuk. 2001. Overrnight borrowing, interest rates and extreme value theory. Bilkent University, Department of Economics Discussion Paper no. 01-03, March. Ankara, Turkey: Bilkent University.

George, S. 2000. A short history of neoliberalism: Twenty years of elite economics and emerging opportunities for structural change. In Global finance: New thinking on regulating speculative capital markets, ed. W. Bello, W. Bullard, and K. Malhotra, 27-35. London: Zed.

Grabel, I. 1995. Speculation-led economic development: A post-Keynesian interpretation of financial liberalization programmes in the third world. International Review of Applied Economics 9 (2): 127-249.

Lippit, V. 1985. The concept of the surplus in economic development. Review of Radical Political Economics $17(1 / 2): 1-19$.

McKinnon, R. 1973. Money and capital in economic development. Washington, DC: Brookings Institution.

Neftçi, S. 1998. FX short positions, balance sheets, and financial turbulence: An interpretation of the Asian financial crisis. CEPA Working Papers 1998-18, June. New York: Center for Economic Policy Analysis, New School for Social Research.

Polanyi-Levitt, K. 2001. Reclaiming the right to development. Paper presented at the UNRISD Conference "Need to Rethink Development Economics," Cape Town, South Africa, September.

Rodrik, D. 2002. After neoliberalism, what? Harvard University. http://ksghome.harvard.edu/ drodrik.academic .ksg/After\%20Neoliberalism.pdf.

— 2003. Growth strategies. Prepared for Handbook of Economic Growth. Harvard University. http:// ksghome.harvard.edu/ .drodrik.academic.ksg/growthstrat10.pdf. 
Rodrik, D., and A. Velasco. 1999. Short term capital flows. In Proceedings of the Annual World Bank Conference on Development Economics, 59-90. Washington, DC: World Bank.

Shaw, E. S. 1973. Financial deepening in economic development. New York: Oxford University Press.

Somel, C. 2003. Estimating the surplus in the periphery: An application to Turkey. Cambridge Journal of Economics 27 (6): 919-33.

Strange, S. 1986. Casino capitalism. Oxford: Basil Blackwell.

Taylor, L. 1998. Lax public sector, destabilizing private sector: Origins of capital market crises. CEPA Working Papers 1998-11, July. New York: Center for Economic Policy Analysis, New School for Social Research.

Turkish Independent Social Scientists Association-Economics Group. 2001. Güçlü ekonomiye geçiş programı uzerine değerlendirmeler. Ankara, Turkey: TMMOB.

Undersecretariat of Treasury. 2001. Transition to the strong economy program. http://www.treasury.gov.tr.

Uygur, E. 2001. Krizden krize Türkiye: 2000 kasım and 2001 subat krizleri. Türkiye Ekonomisi Tartışma Metni (2001/01), Ankara.

Velasco, A. 1987. Financial crises and balance of payments crises: A simple model of Southern cone experience. Journal of Development Economics 27 (1/2) (October): 263-83.

Voyvoda, E., and E. Yeldan. 2002. Beyond crisis adjustment: Investigation of fiscal policy alternatives in an OLG model of endogenous growth for Turkey. Paper presented at the Sixth METU Conference on Economics, September 11-15, Ankara. http://www.bilkent.edu.tr/ yeldane/V\&Yerc2002_1.pdf.

Williamson, J. 1990. The progress of policy reform in Latin America. Washington, DC: Institute for International Economics.

1993. Democracy and the Washington consensus. World Development 21 (8): 1329-36.

Yeldan, E. 1995. Surplus creation and extraction under structural adjustment: Turkey, 1980-1992. Review of Radical Political Economics 27 (2) (Summer): 38-72.

—. 2001a. Birinci yılında 2000 enflasyonu düşürme programının değerlendirilmesi. Mülkiyeliler Birliğgi Dergisi (February).

— 2001b. Küreselleşme sürecinde Türkiye ekonomisi: Bölüşüm, birikim, büyüme. Istanbul: Iletişim Publications.

- 2001c. Türkiye ekonomisinde krizin yapısal dayanakları ya da kriz sürecini bölüşüm eksenine oturtmak uzerine temel değerlendirmeler. Birikim (April).

. 2002. On the IMF-directed disinflation program in Turkey: A program for stabilization and austerity or a recipe for impoverishment and financial chaos? In The ravages of neo-liberalism: Economy, society and gender in Turkey, ed. N. Balkan and S. Savran. New York: Nova Science.

Yenal, O. 2000. Türkiye ekonomisi uzerine değerlendirmeler. Iktisat, Işletme ve Finans (December).

Yentürk, N. 1997. Wage, employment and accumulation in Turkish manufacturing industry (in Turkish). Istanbul: Friedrich Ebert Stiftung.

. 2001. Türkiye ekonomisinin son 20 yılı: Yangın söndü, arsayı kurtardık. Istanbul Technical University. http://www.bagimsizsosyalbilimciler.org/iktisat.htm.

Erinc Yeldan received his PhD from the University of Minnesota and joined the department of economics at Bilkent University in 1988. He served as chair of the economics department between 1998 and 2003. His recent work focuses on development macroeconomics and on computable general equilibrium models with emphasis on the Turkish economy. He is one of the directors of the International Development Economics Associates (IDEAs), New Delhi. 